\title{
Body in Drama Class: The Role of Body in Learning
}

\author{
Necla Köksal ${ }^{1, *}$ \\ ${ }^{1}$ Faculty of Education, Pamukkale University, Denizli, Turkey \\ *Correspondence: Faculty of Education, Pamukkale University, Denizli, Turkey. Tel: 90-258-296-1053. E-mail: \\ nkoksal@pau.edu.tr
}

Received: January 26, 2020

Accepted: March 18, 2020 Online Published: April 6, 2020

doi:10.5430/wje.v10n2p78

URL: https://doi.org/10.5430/wje.v10n2p78

\begin{abstract}
The aim of this study is to examine the perceptions of preservice teachers about the body in drama classes and to identify the views of preservice teachers about the role of the body on learning. As a phenomenological study, the participants consisted of 20 preservice teachers attending the English Language Teaching Department and Psychological Guidance and Counselling Department at the Faculty of Education at Pamukkale University. The data was collected via semi-structured interview form. According to the content analysis, the views of preservice teachers on the body in drama classes were categorized as a theme named "body and learning in drama class". Two sub-themes were identified under the main theme as the impending and supportive factors for learning. As a result, preservice teachers indicated that after the drama experiences their perceptions of the body has changed, they interpreted the relation of body and mind in a different way in the learning process, and comprehend the role of the body on learning better.
\end{abstract}

Keywords: body, drama, perception, learning, phenomenology

\section{Introduction}

Can practice go on without a body? Without bodies? (Green \& Hopwood, 2015, p. 15). This question seems to be a matter for preservice teachers who not only use their body in the learning environments but also have to consider the bodies of their future students. This is because the importance of the body in the learning and teaching process should be questioned where the mind is continuously fostered. As a social being, the individual is in a relationship with other beings and his/her environment through his/her body. The body enables people to exist in the world, to perceive time and space in which he/she belongs to and to interact with the environment and experience it. What's more, experiencing is realized both by developing the body with physical activities and by thinking about the role of the body with regards to learning. Dewey (2007), who asserts that information is obtained through experiences, also states that there are two principles of experience: continuity and interaction. When the learners interact with the environment, the change in their thoughts and their cognitive development are affected positively. In fact, interaction with the environment requires active participation in the learning process both mentally and physically.

Contrary to Descartes who separates mind and body as two completely different selves, Merleau-Ponty (1963) asserts that dualisms such as mind-body or subject-object ignore the body and the key role of the body in reaching information (Primozic, 2013). Ivinson (2012) states his concern regarding the fact that the importance of the body is ignored in reaching information and learning as such: Without obtaining information about relationships between mind and body, thought and learning, who or what questions will depend on rationalism and the role of the body in pedagogical practices will be secondary and unimportant. The student has a body and brings it to the school with the mind. And the body has to do something in this environment as a good energy source (Dewey 1916/1966, 141; Citation: Rothwell, 2011). According to embodied approach, both body and mind are able to produce the knowledge significantly by integrating the physical interaction in learning (Kosmas, Ioannou, \& Zaphiris, 2019). Handling the mind and body as a whole and enabling the active process of the body in the learning process seems to be important in carrying out learning.

Student-centered theories and approaches that enable the student to be mentally and physically active in the learning-teaching process have shaped our education and have been the basis of teaching programs. Because, since Dewey and other progressive educators, the idea that students learn best by doing and through their experiences has 
been popular in theory though not in practice (Bresler, 2004). The consensus on how learning through examples and learning by doing make deep understanding possible for the students (Driscoll, 2005) has been influential to put the student-centered theories into practice. Constructivism, one of these theories, is a theory of knowledge and learning that explains both "knowing" and "how the individual knows" (Fosnot, 2005). Learning in constructivism takes place as a result of the learner's transfer of knowledge through experiences, comparing the existing knowledge with the new knowledge, reinterpreting and making meaning. For meaningful and permanent learning, the learner needs to explore the relationship between the concepts and to participate in the learning process both mentally and physically (Marlowe \& Page, 2005).

As a vivid, interactive and collaborative art form, drama allows people to transform, move, and reflect various styles and approaches (Taylor, 2000; Readman \& Lamont, 1994). It always reveals the emotional dimensions of human relations through physical actions and interactions (Franks, 2014). According to Geraldine Siks (1977), the real interest in drama is about impressive body movements. Children should learn how to use and control their physical self in order to use body movements that shape their impulses and imaginations in a meaningful way (O'Toole, 2009). Individuals learn to use their bodies effectively in different roles in drama events, and thus learn to develop their imaginary worlds and to become empathic.

As a method, drama allows learners to participate physically in each phase of a lesson and to develop emotionally, mentally and socially. Drama is a comprehensive method of traditional classes that lack quality and quantity in the past, including physical movement, voice action, and mental concentration (Toivanen, Komulainen, \& Ruismaki, 2011). Creative drama method helps students to perceive both the physical places in which they are in the places they visualize during the activities through utilizing their bodies and sense organs efficetntly (Kiliscaslan, 2016). This method enables individuals to give meaning and portray an experience, a phenomenon, an idea, an abstract concept or behavior in group work by using techniques such as improvisation and role-playing (Adigüzel, 2013; San, 2002). As mentioned in the definitions, drama activities are student-centered and students act and motivate to learn more emotionally and more intellectually because they reflect their personal life experiences on drama studies (Hertzberg, 2004; Miccoli, 2003; Liu, 2000; Kao \& O'Neill, 1998; Stern, 1981; Citation Ntelioglou, 2012). Students play a role in the drama actions designed for them, analyse their roles, recognize themselves and their environment and collaborate on creative tasks.

For school teaching, drama can enable children to participate more actively in the classroom, effectively attract children's interes, stimulate their desire to explore, enhance the aesthetic ability of art, and meet the educational and teaching needs of theachers and schools ( $\mathrm{Du}, \mathrm{Xu}, \&$ Jang, 2019). Nicholson (2005) asserts that drama is particularly well developed to contribute to learning approaches that counter authoritarian education (banker education), and moreover it not only presents an opportunity for a dialogue between teacher and student (as Freier asserts) but also based on the interaction and change between the participants (Ntelioglou, 2012). Vygotsky's theory of social constructivism is one of the learning approaches which underlines that the interaction between learners should be at the highest level. Learning in social constructivism is created through interactions with other individuals in a particular socio-cultural context (Oldfather, West, White, \& Wilmarth; 1999; Citation Dervishaj, 2009). The theoretical foundations of the drama based education invite the teachers (1) to construct a student community based on a dialog between students and teachers (Vygotsky, 1978), and (2) to change into constructive and/or interactive teaching strategies (Fonseca \& Chi, 2008) rather than passive and/or active teaching strategies (Lee, Cawthon \& Dawson, 2013). Another learning approach is Gardner's multiple intelligence theory. Cooperative group work in classrooms where multiple intelligence theories are applied is particularly appropriate because such studies can be structured to include students who represent all areas of intelligence (Armstrong, 2009). The drama method, which is effectively applied in such learner-centered approaches, enables the individual to use his/her mind and body in a harmonious manner while constructing the meaning.

Individuals who learn by acquiring original educational experiences in collaborative environments gain a number of skills in this process. These include creativity, originality, sensitivity, fluency, flexibility, cooperation and teamwork, conflict resolution, empathy and tolerance, effective communication, respect for others and the environment, self-esteem, thinking skills and self-confidence (Hoetker, 1969; Citation Dervishaj, 2009; Chalmers, 2007; Rainer and Lewis, 2005). With the drama lesson in the curricula of teacher education, it is aimed to provide teacher candidates with these skills as well as to enable them to realize effective teaching activities. In this context, Toivanen, Komulainen and Ruismaki (2011) list the purposes of using drama as a teaching method in teacher education as follows: To increase the awareness of teacher candidates about themselves (mind, body and voice) and others (cooperation and empathy); to increase the interaction skills of teacher candidates; to develop clarity and creativity in the communication of verbal and nonverbal thoughts; to increase understanding of human behavior, motivation and 
diversity in educational situations.

A body of research handled drama as a method in teaching a concept or subject in the literature (Keleş, 2015; Adomat, 2012; McNaughton, 2004), in teaching language (Anderson \& Loughlin, 2014; Kalidas, 2013; Steele and Kelin, 2012; Dunn, Bundy \& Woodrow, 2012; Dervishaj, 2009), and in teaching different skills such as thinking skills, communication skills, teaching skills (Lehtonen, Kaasinen, Karjalainen-Vakeva \& Toivanen, 2016; Wright, 2015; Albalawi, 2014; Toivanen, Komulainen, \& Ruismaki, 2011; Pitfield, 2012; Freebody, 2010; Şengül \& Üstündağ, 2009; Kara \& Çam; 2007; Freeman, Sullivan, \& Fulton, 2003). Body, the dimensions of which are studied in every discipline seems to be associated with learning and pedagogical practices more. (Mavilidi et al., 2015; Ruiter, Loyens \& Paas, 2015; Benzer, 2015; Alibali \& Nathan, 2012; Sparkes \& Smith, 2011; Ivinson, 2011; Lussier-Ley, 2010). There are also studies in which body and drama are studied together (Ramsay, 2014; Gürey \& Adıgüzel, 2013; Perry \& Medina, 2011). In these studies, dimensions such as body use, body awareness and expressing dance movement skills with the body and role of the body in performance pedagogy are discussed.

In his research on reconstruction of the body in teaching and learning, Hunter (2011) indicates that there has been much research lately on the body in teaching environments. On the other hand, Reid and Mitchell (2015) emphasize that in the research of teaching and teacher education, the body is not referred enough. With the current research, a contribution to the literature is aimed by the body in drama courses in the curricula of teacher education. Moreover, by discussing the role of the body on learning, the importance of physical activity is emphasized not only for young learners but also for young adults. Teacher candidates who participate in drama lesson, which is included as a compulsory or elective course in many departments in Turkey, learn what is drama as a discipline as well as how to apply it in their branches as a method. Teacher candidates use their bodies in drama lessons most effectively, except for lessons such as physical education, dance, folk dances, and educational games. In this context, it is aimed to determine the perceptions of teacher candidates about the body in the drama lesson and the thoughts about the role of the body in learning in this study.

\section{Methodology}

\subsection{Research Design}

The study was designed as phenomenological research which is a qualitative research design. According to Merleau-Ponty, phenomenology aims to explain in a comprehensive way our lives and the whole horizon of the present world (or limit) by trying to describe faithfully and authentically the phenomena that make up these experiences (Primozic, 2012). Phenomenological research aims to establish a reconfigured relationship with original experience (van Manen, 1990). In the research, common meanings are formed from individual experiences about the "body" concept that participants use effectively in drama activities.

\subsection{Participants}

Participants of the study consisted of third-year students attending the Department of English Teaching $(n=9)$ and the Department of Psychological Counselling and Guidance $(n=11)$ in the Faculty of Education, Pamukkale University and taking drama courses. In this context, the participants are identified by means of the easy-to-reach sampling method of purposeful sampling methods. As the courses are given by the researcher in both departments and so the same activities are carried out, all the volunteer teacher candidates are included in the study. Nine women from English Teaching, nine women and two men from Psychological Counselling and Guidance, in total, 20 teacher candidates participated in the study. Because of ethical concerns in the research, P-code is given to Psychological Counselling and Guidance students and E code to English language teacher candidates along with 1-20 numbers.

\subsection{Data Collection Tool}

The data is collected through a semi-structured interview form consisting of 14 questions. To develop the interview form, questions are first structured from the related literature. A specialist from the curriculum and instruction department and a sociologist who has much research on body gave feedback for the interview form in terms of grammar, clarity and subject-question appropriateness (Glesne, 2013). A pilot interview is held with two students who had taken the drama course in the previous year to determine the functionality of the draft interview form finalized in line with the opinions of the experts. The pilot interviews are tested whether the questions are clear and understandable and whether they are perceived in the same way by the participants. After two expert opinions and two pilot applications, the semi-structured interview form is finalized.

The interview form, which was prepared to reveal the participants' experience and perceptions of the body in the drama class, consists of 14 open-ended questions and probes. The first question contains personal information about 
the participants. Other questions are about participation in all classes, physical activity in class, participation in drama lessons, use of the body in drama lessons, the perception of body in drama lessons, and the role of the body in learning.

The day and time of the interview were determined, and the interviews were held at the researcher's office. All the teacher candidates were recorded with a voice recorder in the condition of their permission. Interviews were completed between 24 and 43 minutes.

\subsection{Data Analysis}

Content analysis is used for analysing the data to determine the participants' individual meanings for the body concept and the circumstances under which this experience of the concept occurs. Special techniques such as deliberate sorting, framing, phenomenological reduction, and creative variation can be used in the analysis process of the data since it is aimed to reveal the basic structure of the phenomenon in phenomenological researches (Merriam, 2013).

In this study, the data obtained by the voice recorder was first deciphered and the data was transcript. The dataset was read twice by the researcher uninterruptedly and the appearance of meaningful data units was tested. After this step, the draft code list was created firstly using the literature and the dataset. In the second stage, important expressions were identified by removing repetitive and unrelated phrases. As for the third phase, these important expressions were grouped as meaningful units and the themes were structured. Thus, what participants experienced, how they experienced and their perceptions related to the phenomena were explained. In the reporting phase, the themes were written as the titles for the readers to perceive the findings integrative. After the description of the themes, the codes that were revealed under the related themes were written and the findings of the themes were directly supported by the quotations.

\subsection{Validity and Reliability}

One of the strategies used to provide internal validity in research is triangulation. As for the current research, multiple data sources (1978; Citation; Merriam, 2013), one of the four types of triangulation proposed by Denzin, were used. For this purpose, interviews were held with the students who are girls and boys with different perspectives who are educated in two different departments, wearing a headscarf or not, actively engaged with theatre and sports. After the findings were written down, the participants were asked whether the comments reflect their views. In order to provide external validity, a detailed description of the methodology, participants, data collection tools and findings were presented, and direct citations were applied to in the presentation of the findings. While presenting the findings, in order to provide reliability, different, contradictory, negative and positive representations of the codes were given to enable the understanding of the theme in a broad context.

\section{Results}

The experiences of the participants in drama classes are structured as a theme named "body and learning in drama class". Under this theme, there are two sub-themes as the supportive and preventing factors for learning

Table 1. Body and Learning in Drama Class

\begin{tabular}{lc}
\hline Factors supporting learning & Factors preventing learning \\
\hline Being energetic & Perceived gender roles \\
Being happy & Being a woman \\
Permanent learning & Participants from the opposite sex \\
Funny learning & Anxiety for attractive organs appearance \\
Make easy to remember & Negative views of friends \\
Recognize the mistakes & Personal traits \\
Gaining experiences & Timid \\
Aware of the limits of the body & Calm \\
Developing the body language & Active \\
Harmony of body and mind & Open to communication \\
\hline
\end{tabular}




\subsection{Factors Supporting Learning}

To reveal whether being mentally and also physically active in the classes contribute to a change in behavior is considered to be a significant finding for the current research. Analysis of the dataset showed that participants stated their views regarding that body supports learning in terms of to be energetic, to be happy, to learn permanently, to learn by amusing, to facilitate remembering, to see mistakes and gain experience. Participants indicated that their energy increases when they are intensely physically active in classes. P-14 indicated that when his/her energy increases, $\mathrm{s}$ /he focuses on the classes better and said that "When I am active, I feel different. In terms of energy, I can focus [on the class] better." E-20 said, "I feel more vibrant, energetic and I feel the need to participate in things. Otherwise, when I sit down, everything becomes very boring", and emphasizes that physical participation encourages $\mathrm{him} / \mathrm{her}$. Students think that they are more likely to learn better when they are physically attending the classes. They stated that using the body in the tasks actively makes it easier to remember and provides the permanency. Statements of some participants' views are given below:

"I can be more motivated and this enables it to become permanent. When I don't do it with my body, I can't concentrate one hundred percent. But when I do it myself, it becomes more beneficial in terms of being permanent and learning (E-5)

"When I am included in something, it makes me feel like I learn more, so it is a good feeling to be in every activity and I think every student should feel that. By this way, the classroom becomes more enjoyable and learning becomes better." (E-18)

"I don't forget the things we do with our movements. And I can remember them easily when I want to use them later. Also, it is more fun. I can think permanently when I apply the things I learn." (E-20)

Students indicated that they live different experiences when they actively participate in drama classes unlike in the other lessons. They also added that this experience provides some kind of advantages in terms of learning and professional development. P-12 said that he/she can see his/her mistakes in practices, while E-13 stated that practices help him/her to be prepared as a teacher, and expressed their views as follows:

"I can see the mistake more clearly when I am involved. For example, if someone explains it, I can think that I understand, but I realize later on that something is missing when I work on it. But when I am involved, I can notice at that time. It makes me feel better. Sometimes it is difficult since I don't know what exactly I will do, but I generally feel fine." (P-12)

"Thanks to such classes, I feel closer to being a teacher. I feel more relaxed in terms of teaching. I gain experience on the stage." (E-13)

Merleau-Ponty asserts that the living body expresses himself with the way of existence, gestures, laughter, speech, and behavior in this world (Direk, 2003). Students who actively use their bodies in the drama classes express their bodies with different forms of behavior in every activity in order to learn. At the end of such a process, the participant's perceptions about the body concentrate on the awareness of the body's limits, body language development, and mind-body harmony. E-3 stated that he/she realizes the limits of the body in the activities during the class and expressed his/her views as: "We mentioned many objects and prepared photo frames, created a symbol and tap out the rhythm with our bodies. I didn't think we would be able to do so many things. It really broadens my perspective in terms of body." Similarly, E-5 said, "I was able to do things that I thought I couldn't and I realized that I do those things with my body. Therefore, I think students should be given the same opportunity in classes", and in this sense s/he inferred for the teaching profession about the active use of the body in classes.

Participants stated that they have realized the importance of body language in communication with the others, and they express more easily what they try to say and they start to use their gestures and mimics effectively. Merleau-Ponty asserts that mind and body are not two separate things, physical life is full of mental life and mental life is also full of physical life also (Primozic, 2012). Some participants also made similar statements. P-2 who stated to harmonize the mind and body affects learning positively said, "Mind can get tired and give up easily...But when it works together with the body, it starts to enjoy and dance. This enables me to learn quicker." Moreover, P-16 said, "I realized my body more. I think that I have reached to the freedom of expressing what I think mentally as physically in terms of my movements by the help of drama."

\subsection{Factors preventing learning}

Unlike the other classes, the drama is a course which is performed not in a classroom but in a workshop environment. What's more, students sit on the cushions or stand, and actively participate and use their bodies intensively in the 
drama classes. To reveal whether perceived gender roles and personal traits support the physical experience in drama classes was considered important for the research findings and each was handled as a sub-theme. In the concept of these sub-themes, being a woman, participants from the opposite sex, anxiety about the appearance of body parts, negative views of friends, and personal traits such as being shy, calm, active, open to communication were determined as significant. Students' views about the perceived gender roles were given below:

"Since I'm a girl... of course, there are some situations that we should be more careful about in society. I am careful about that. Anyway, it comes from the family. For example, I don't like crossing my legs or such things." (P-11)

"it occurs because I am a girl. But I don't restrict myself too much... But I sometimes limit myself. I try to be careful about how I sit. I don't lift my legs or arms up too much, for example." (E-3)

Woman participants pointed out that the most important point limiting their behaviors is being a woman. According to the research findings, the participants felt social pressure to perform some body movements and did not take any actions that they thought would be inappropriate. They said that they think they are misunderstood when they act such that. Another limiting factor of the behaviors of the participants is the existence of the opposite sex. Two of the students with headscarves mentioned this situation and described their views as follows:

"I am normally careful if there are too many people from the opposite sex in the room... But it depends on which movement I do. I am not bothered with my arm or foot movements or how I walk, but if I need to do bigger movements, if I have to lay down, I try to keep my legs together." (P-7)

"If there are men in the room, I can't move freely. I have to be careful about how I sit or about my movements of course. In fact, I don't feel any disturbance with the people of the same gender. Of course, well as a principle or an approach of myself, I talk with my friends from the opposite sex. And I am not very strict about touching in the drama class, but I am disturbed by it." (P-19)

Students' limiting themselves in physical movements can be explained in relation to their lifestyle and their perspectives. In the same issue, one of the male participants stated that he limits his movements because he thinks that the female participants would have difficulty. P-14 said, "Improvisation is different, but when there is a girl, I still think if it would be misunderstood or difficult for her. Because girls are more careful about such a thing" and stated that he avoided movements that may disturb female participants.

Personal traits are structured among the factors that limit learning. Participants identified themselves as timid, calm, active and open to communication. They indicated that these traits cause a limitation for participation in the activities and communicating. E-5 who identifies him/herself as an active person described his/her communication skills as such: "I am not a very calm person, but an active one. Either in any social environment or with my friends. But I can't communicate right away. I observe the environment at first". P-1 also said that he/she is shy and expressed his/her reasons why s/he has some troubles with the improvisations at the drama classes such that "I usually expect the first step from the others because I feel a bit shy about it".

Although four of the participants are open to communication, they state that they act according to the conditions, and they do not feel comfortable in a formal environment. However, they are comfortable expressing themselves in the drama classes because there is no such problem around their friends.

\section{Discussion}

Teacher candidates desire mental and physical activity participation in the classes in order to make the learner more productive, and that the learning-teaching environments should be organized to support this participation. Freire (1998) asserts that students become aware not when they become passive receivers, but when they participate to the knowing process as active subjects and critical thinkers who have a deep awareness (Yıldırım, 2010; Dervishaj, 2009). Most experts agree that when students take an active role in the learning process the student's learning is optimized (Smart \& Csapo, 2007; Citation McCarthy \& Southeastern, 2016). In drama education, the student is responsible for understanding and defining his own learning. The student is described as one who emotionally forms a meaning with an embodied experience (Wright, 2007). Individuals participating in the learning process as active subjects in drama courses constitute their own original knowledge structures. Teacher candidates, who will conduct constructive curricula developed by the Ministry of National Education in their future classes, desire to be active both mentally and physically in learning environments. Hence, this is considered to be an important finding in terms of knowing the philosophy of the curriculum, as well as the needs of the learners. 
Teacher candidates who make active body movements in drama lessons explain the contribution of the body to learning by relating it to being energetic and happy, learning by having fun, making the learning more permanent, easier recalling of learning and gaining experience for the teaching profession. It is found that teacher candidates are energetic and happy in the active learning environment (Oğuz \& Şahin, 2014; Çerkez et. al, 2012; Toivanen, Komulainen \& Ruismaki, 2011; Başc1 \& Gündoğdu, 2011; Okvuran, 2003), and also the activities in drama classes increases their awareness and provide experience (Tanrıseven, 2013; Topcuoglu Unal, 2013; Pitfield, 2012; Perry \& Medina, 2011; Capponi et. al., 2010). One of the important results of the study is the contribution of the body to the permanence and remembrance of learning. Teacher candidates remember and use the knowledge they learn in the drama settings later in exams or other courses' practices. Rothwell (2011) found in his study that cognitive, emotional and physical experiences are the result of learning to be more real and memorable. Furthemore, Başc1 \& Gündoğdu (2011) examined the views of pre-service teachers on drama and found that drama classes have an important impact on their motivation and permanence of their learning. Besides, in an experimental study by Oğuz \& Şahin (2014) in which they investigate the effects of creative drama on art education achievements of teacher candidates and their interest in arts, participants in the study group emphasized more "permanent learning" than the control group did. In this sense, what Franks (2015) asserts that the creation of meaning through drama and the drama itself is most obviously done with socially organized and cultured. Thus, individuals make their experiments permanent by constructing and living the knowledge they understand with the help of their own bodies.

Another significant finding of the study is that sharing the same environment with the opposite sex and the possible appearance of the body parts limit the teacher candidates' body actions. What's more, female teacher candidates have experienced more hindrances in their body movements than males. The woman body, which is restricted by prevailing cultural values and social pressures, also cannot act freely in drama classes. In a related manner, Satina \& Hultgren (2001) point out that girls' bodies are traditionally and culturally rendered, and thus become non-existent assets in the learning environment, including physical education. Moreover, they emphasize that a somatization pedagogy which encourages students to develop their awareness of the body will emerge and that this is particularly important for girls who are traditionally restricted to sexist roles during physical activity. In line with the literature, social pressure and gender roles make it impossible for women learners to benefit from their bodies not only in drama courses but also in different learning environments.

In this study, teacher candidates expressed a change in their perceptions of their bodies in drama classes. Teacher candidates think that being aware of the limits of their own physical activities encourages them to make a bodily action, and also it highlights the importance of creating such practice environments for their own students in the future. Furthermore, there also some views on that the practices in the drama classes contribute to the development of body language. For example, it was observed that teacher candidates have developed gestures and mimics over time in improvisations and communicate more effectively through their bodies. There are many studies in the literature supporting this result (Mavilidi et. al, 2015; Benzer, 2015; Topcuoglu Unal, 2013; Gürey \& Adıgüzel, 2013; Rothwell, 2011). Teacher candidates, who are aware of the importance of voice tone, eye contact, gesture, and mimics as well as the words for effective communication, stated that pair and group improvisations are useful for conveying feelings and thoughts to the body for the development of the aforementioned. In this study, teacher candidates particularly underlined the change of their perceptions about body and mind. It is strikingly observed that the assertion that the mind is more important than the body in learning, and body just helps the mind in constructing the meaning has been evolved. Merleau-Ponty indicates that mind and body are not two separate things, physical life is full of mental life and mental life is also full of physical life (Primozic, 2012). Accordingly, teacher candidates also experienced the integrity of body and mind in drama classes.

For all learners to learn by doing, it is suggested to include all the methods, techniques, and activities that activate the body in learning environments. Drama is one of these methods, and Dewey $(1897 ; 2000)$ state that the games in drama activities are constructive activities which give experience and in turn, it answers to the interests and needs of the students in the learning process (Saebo, 2009). The most important goal of drama is to make students gain a deeper understanding by taking into consideration the different points of view of the students (O'Loughlin, 2006). In the current study, teacher candidates also indicate that their bodies have contributed positively to their deep understanding of their own learning in the drama process. In this case, in-depth research on body and learning relation might be conducted in different courses as well as in courses such as drama or physical education. Regarding this subject, Franks (2015) also mentions the relationship between performance, culture, and learning and emphasizes that we have to continue to develop theoretical and methodical tools to make body, drama, and learning clearer.

Perry \& Medina (2011) studied the role of the body in the performance pedagogy in the workshop carried out with 
teacher candidates. A drama-based phenomenon in the study was used to analyze the learning areas and aspects that may arise in performance-based pedagogical practice. In a class-based drama activity, the participants who have the knowledge of drama and pedagogy used physical, visual and textual discourses of performance and achieved positive results. In order to make a further contribution to the professional development of the teacher candidates, it is proposed that candidates might prepare and implement instructional designs related to physical activities in the pedagogical formation courses. In this respect, Latta \& Buck (2008) state that revealing the place and role of the body in teacher education strengthens the learners and teachers and encourages them to learn.

According to Ivinson (2012), without understanding more about relations between minds and bodies, questions about 'who' (agency) or 'what' (matter) does the thinking and learning will remain narrowly bound to rationality and the role of bodies within pedagogic practice will remain allusive, secondary and trival. The most encouraging result in this study is that the role of the body in learning is not secondary and insignificant. When teacher candidates take an active role in drama process; they empsasize than meaningful and permanent learning take place, that they learn by having fun in cooperative environments and that they communicate effectively not only with their close friends but also with all class mates. In addidion, it is seen as an importans result that female teacher candidates feel unconfortable from various cultural reasons and express this in physical activities in drama classes. This result can be considered as a key finding for the design of studies with cultural dimensions related to the body.

The results of this study indicate that teacher candidates have positive thoughts on both drama classes and their own bodies. Nevertheless, the study reveals only the results based on the perspective of the participants, so it is suggested that different studies supported by reflective journals and observations are conducted. Learning occurs in not only the mind but also social contexts and bodies (Freiler, 2008). That's why the role of the body in learning is regarded as significant, and the drama course might give this opportunity as it provides an active use of the body. Rather compulsory or selective, drama classes in teacher training might increase body awareness and enrich the instructional activities. Consequently, the learning process might become easier, enjoyable and meaningful for participants.

\section{References}

Adıgüzel, Ö. (2013). Creative drama in education. Ankara: PegemA Academy.

Adomat, D. S. (2012). Drama's potential for deepening young children's understandings of stories. Early Childhood Education Journal, 40, 343-350. https://doi.org/10.1007/s10643-012-0519-8

Albalawi, B. R. (2014). Effectiveness of teaching English subject using drama on the development of students' creative thinking. Journal of Research and Method in Education, 4(6), 54-63. https://doi.org/10.9790/7388-04615463

Alibali, M. W., \& Nathan, M. J. (2012). Embodiment in mathematics teaching and learning: evidence from learners' and teachers' gestures. Journal of the Learning Sciences, 21(2), 247-286. https://doi.org/10.1080/10508406.2011.611446

Anderson, A., \& Loughlin, S. M. (2014). The influence of classroom drama on English learners' academic language use during English language arts lessons. Bilingual Research Journal, 37(3), 263-286. https://doi.org/10.1080/15235882.2014.965360

Armstrong, T. (2009). Multiple intelligence in the classroom. USA: Association for Supervision and Curriculum Development.

Arnold, J., \& Fonseca, M. C. (2004). Multiple intelligence theory and foreign language learning: a brain-based perspective. International Journal of English Studies, 4(1), 119-136.

Başc1, Z., \& Gündoğdu, K. (2011). The attitudes and opinions of prospective teachers related to drama course: the case of Atatürk University. Elementary Education Online, 10(2), 454-467.

Benzer, A. (2015). The role of using body language in Turkish teaching on learning and attitude. Hacettepe University Journal of Education, 30(1), 33-47.

Bresler, L. (2004). Dancing the curriculum: Exploring the body and movement in elementary schools. In L. Bresler (Eds.), Knowing bodies, moving minds (pp. 127-152). Urbana-Champaign: Kluwer Academic Publishers.

Capponi, M. F., Nussbaum, M., Marshall, G., \& Lagos, M. E. (2010). Pattern discovery for the design of face-to-face computer-supported collaborative learning activities. Educational Technology \& Society, 13(2), 40-52.

Çerkez, Y., Altınay, Z., Altınay, F., \& Bashirova, E. (2012). Drama and role playing in teaching practice: the role of 
group works. Journal of Education and Learning, 1(2), 109-120. https://doi.org/10.5539/jel.v1n2p109

Chalmers, D. (2007). Drama 3-5 a practical guide to teaching drama to children in the foundation stage. UK: Routledge.

Dervishaj, A. (2009). Using drama as a creative method for foreign language acquisition. LCPJ, 2(1), 53-62.

Dewey, J. (2007). Experience and education. (Translate. Sinan Akıllı). Ankara: METU Publishing.

Direk, Z. (2003). The world's skin analysing on Merleau-Ponty philosophy. İstanbul: Metis Publish.

Driscoll, M. P. (2012). Psychology of learning for instruction. In Ö.F. Tutkun, Translate. (Ed.), Ankara: Anı Publishing.

Du, Y., Xu, L., \& Jiang, Z. (2019). Research on the present situation and strategy of kindergarten children's drama education in Xi'an. Advances in Social Science, Education and Humanities Research, 341, 616-620.

Dunn, J., Bundy, P., \& Woodrow, N. (2012). Combining drama pedagogy with digital technologies to support the language learning needs of newly arrived refugee children: a classroom case study. Research in Drama Education: The Journal of Applied Theatre and Performance, 17(4), 477-499.

Fosnot, C. T. (2005). Constructivism theory, perspectives and practice. New York: Teachers Collage Press.

Franks, A. (2014). Drama and the representation of affect-structures of feeling and signs of learning. Research in Drama Education: The Journal of Applied Theatre and Performance, 19(2), 195-207. https://doi.org/10.1080/13569783.2014.895614

Freebody, K. (2010). Exploring teacher-student interactions and moral reasoning practices in drama classrooms. Research in Drama Education: The Journal of Applied Theatre and Performance, 15(2), 209-225. https://doi.org/10.1080/13569781003700094

Freeman, G. D., Sullivan, K., \& Fulton, C. R. (2003). Effects of creative drama on self-concept, social skills, and problem behavior. The Journal of Educational Research, 96(3), 131-138. https://doi.org/10.1080/00220670309598801

Freiler, T. J. (2008). Learning through the body. New Directions for Adult and Continuing Education, 119, 37-47. https://doi.org/10.1002/ace.304

Glesne, C. (2013). Becoming qualitative researchers: An introduction (Translate Ali Ersoy - Pelin Yalçınoğlu). Ankara: Anı Publishing.

Green, B., \& Hopwood, N. (2015). The body in professional practice, learning and education. Australia: Springer.

Gürey, B., \& Adıgüzel, Ö. (2013). Developing dance body movement skills and body awareness with creative drama. Journal of Creative Drama, 8(15), 1-27.

Hunter, L. (2011). Re-embodying (preservice middle years) teachers? An attempt to reposition the body and its presence in teaching and learning. Teaching and Teacher Education, 27, 187-200. https://doi.org/10.1016/j.tate.2010.07.016

Ivinson, G. (2012). The body and pedagogy: beyond absent, moving bodies in pedagogic practice. British Journal of Sociology of Education, 33(4), 489-506. https://doi.org/10.1080/01425692.2012.662822

Kalidas, C. S. (2013). Drama: a tool for learning. Procedia-Social and Behavioural Sciences, 123(2014), 444-449. https://doi.org/10.1016/j.sbspro.2014.01.1443

Kara, Y., \& Çam, F. (2007). Effect of creative drama method on the reception of some social skills. Hacettepe University Journal of Education, 32(2007), 145-155.

Keleş, Ö. (2015). Creative drama in the teaching of education for sustainable development: sample activity about sustainability and sustainable production. Journal of Environmental Sustainability, 4(4), Article 4.

Kılıçaslan, H. (2016). Creative drama in design education within the context of theatre, body and space. International Journal of Humanities and Social Science Invention, 5(7), 9-15.

Kosmas, P., Ioannou, A., \& Zaphiris, P. (2019). Implementing embodied learning in the classroom: effects on children's memory and language skills. Educational Media International, 56(1), 59-74. https://doi.org/10.1080/09523987.2018.1547948

Latta, M. M., \& Buck, G. (2008). Enfleshing embodiment: 'falling into trust' with the body's role in teaching and 
$\begin{array}{llll}\text { learning. } & \text { Educational } & \text { Philosophy } & \text { Theory, }\end{array}$ https://doi.org/10.1111/j.1469-5812.2007.00333.x

Lee, B., Cawthon, S., \& Dawson, K. (2013). Elementary and secondary teacher self-efficacy for teaching and pedagogical conceptual change in a drama-based professional development program. Teaching and Teacher Education, 30, 84-98. https://doi.org/10.1016/j.tate.2012.10.010

Lehtonen, A., Kaasinen, M., Karjalainen-Vakeva M., \& Toivanen, T. (2016). Promoting creativity in teaching drama. Procedia Social and Behavioural Science, 217(216), 558-566. https://doi.org/10.1016/j.sbspro.2016.02.046

Lussier-Ley, C. (2010). Dialoguing with body: a self study in relational pedagogy through embodiment and the therapeutic relationship. The Qualitative Report, 15(1), 197-214.

Marlowe, B. A., \& Page, M. L. (2005). Creating and sustaining the constructivist classroom. ABD: Corwin Press.

Mavilidi, M. F., Okely, A. D., Chandler, P., Cliff, D. P., \& Paas, F. (2015). Effects of integrated physical exercises and gestures on preschool children's foreign language vocabulary learning. Educational Psychology Review, 27(3), 413-426. https://doi.org/10.1007/s10648-015-9337-z

McCarthy, M., \& Southeastern, N. (2016). Experiental learning theory: from theory to practice. Journal of Business \& Economics Research, 14(3), 91-99. https://doi.org/10.19030/jber.v8i5.725

McNaughton, M. J. (2004). Educational drama in the teaching of education for sustainability. Environmental Education Research, 10(2), 139-155. https://doi.org/10.1080/13504620242000198140

Medina, C. L. (2004). The construction of drama worlds as literary interpretation of Latina feminist literature. Research in Drama Education: The Journal of Applied Theatre and Performance, 9(2), 145-160.

Merriam, S. B. (2013). Qualitative book a guide to design and implementation (Translate. Ed: Selahattin Turan). Turkey, Ankara: Nobel Publishing.

Ntelioglou, M. B. Y. (2012). Drama pedagogies, multiliteracies and embodied learning: urban teachers and linguistically diverse students make meaning. Unpublished $\mathrm{PhD}$ Dissertation. University of Toronto, Canada.

O'Loughlin, M. (2006). Embodiment and education. The Netherlands: Springer.

O’Toole, J. (2009). Drama for development and expression. (Ed: O'Toole, J. Stinson, M. and Moore, T.). Drama and curriculum. Springer.

Oğuz, A., \& Şahin, A. E. (2014). The effect of creative drama on pre-service elementary teachers' achievement in art education course and interest in art. International Journal of Progressive Education. 10(3), 109-126.

Okvuran, A. (2003). Efficiencies of drama teacher. Ankara University Journal of Faculty of Educational Sciences, 36(1-2), 81-87. https://doi.org/10.1501/Egifak_0000000070

Perry, M., \& Medina, C. (2011). Embodiment and performance in pedagogy research. Investigating the possibility of the body in curriculum experience. Journal of curriculum theorizing, 27(3), 62-75.

Pitfield, M. (2012). Transforming subject knowledge: drama student-teachers and pursuit of pedagogical content knowledge. Research in Drama Education: The Journal of Applied Theatre and Performance. 17(3), 425-442. https://doi.org/10.1080/13569783.2012.694038

Primozic, D. T. (2012). On Merleau-Ponty. (Translate Z. Zafer Esenyel). Bursa: Sentez Publishing.

Rainer, J., \& Lewis, M. (2005). Teaching drama and theatre in the secondary school. USA: Routledge.

Ramsay, A. (2014). Girls' bodies, drama and unruliness. Research in Drama Education: The Journal of Applied Theatre and Performance, 19(4), 373-383. https://doi.org/10.1080/13569783.2014.954817

Readman, G., \& Lamont G. (1994). Drama: A Handbook for Primary Teachers. London: BBC.

Reid, J., \& Mitchell, D. M. (2015). Inhabiting a teaching body: portraits of teaching. In B. Green \& N. Hopwood (Ed.), The Body in Professional Practice, Learning and Education. Australia: Springer.

Rothwell, J. (2011). Bodies and language: process drama and intercultural language learning in a beginner language classroom. Research in Drama Education: The Journal of Applied Theatre and Performance, 16(4), 575-594. https://doi.org/10.1080/13569783.2011.617106

Ruiter, M., Loyens, S., \& Paas, F. (2015). Watch your step children! Learning two-digit numbers through mirror-based observation for self-initiated body movements. Educational Psychology Review, 27(3), 457-474. 
Saebo, A. B. (2009). Challenges and possibilities in Norwegian classroom drama practice. Research in Drama Education: The Journal of Applied Theatre and Performance, 14(2), 279-294. https://doi.org/10.1080/13569780902868952

San, İ. (2002). Creative drama in education, 1985-1995, articles, (1. volume). Turkey, Ankara: Naturel Publishing.

Satina, B., \& Hultgren, F. (2001). The absent body of girls made visible: embodiment as the focus in education. Studies in Philosophy and Education, 20, 521-534.

Şengül, C., \& Üstündağ, T. (2009). Critical thinking disposition levels of physics teachers and state of critidal thinking in classroom activities. Hacettepe University Journal of Education, 36, 237-248.

Sparkes, A. C., \& Smith, B. (2011). Inhabiting different bodies over time: narrative and pedagogical challenges. Sport, Education and Society, 16(3), 357-370. https://doi.org/10.1080/13573322.2011.56596

Steele, J. S., \& Kelin, D. A. (2012). Dramatic differences: the power of play building for young English language learners. The Tapestry Journal, 4(2), 19-31.

Tanriseven, I. (2013). The effect of school practices on teacher candidates' sense of efficacy relating to use of drama in education. Educational Sciences: Theory and Practice, 13(1), 389-412.

Taylor, P. (2000). The drama classroom: action, reflection, transformation. UK: Routledge.

Toivanen, T., Komulainen, K., \& Ruismaki, H. (2011). Drama education and improvisation as a resource of teacher student's creativity. Pracedia Social and Behavioral Scinences, 12, 60-69. https://doi.org/10.1016/j.sbspro.2011.02.010

TopcuoğluUnal, F. (2013). Perception of teacher candidates with regard to use of theatre and drama applications in Education. Anthropologist, 16(3), 513-521. https://doi.org/10.1080/09720073.2013.11891377

vanManen, M. (1990). Researching lived experience. Human science for an action sensitive pedagogy. USA: State University of New York Press.

Wright, D. (2007). Constructivist inquiry and learning in drama. NJ., 31(1), 45-54.

Yıldırım, A. (2010). Critical pedagogy Ivan Illich and Paulo Freire's understanding of education. Akara: Anı Publishing. 